\title{
POLYETHYLENE SURFACE MODIFICATION BY SOLAR ELECTROSTATIC DISCHARGE SYSTEM FOR EXTEND SHELF LIFE OF SWEET PEPPER
}

\author{
${ }^{1}$ Entsar Kh.G. Ahmed; ${ }^{2}$ Atef M. Elsbaay; \\ ${ }^{3}$ Nabihah H. AbouElhana; and ${ }^{4}$ Mahmoud E. El-iraqi
}

\begin{abstract}
Nowadays, the new and renewable energy is one of the main concern, especially the solar energy which is considered as new and renewable energy instead of other traditional energies. Therefore, the scientific research in the field of unconventional energy sources has increased due to its easy of use and low cost, as well as not polluting the environment. The main objective of this study is using of solar photovoltaic cells for operating a locally manufactured electrostatic charging unit, which used to charge and modify polyethylene sheet surface as packaging materials for extend shelf life of sweet pepper. This study was carried out at Agriculture Engineering Department, Faculty of Agriculture, KafrElsheikh University, KafrElsheikh Governorate $\left(31.07 N^{\circ}\right.$ and $30.57 E^{\circ}$ ), Egypt during the period from June to September, 2016. The electrostatic charge unit, consists of a converting unit from low voltage to the required high voltage, which connected with control unit adjust charging speed of the polyethylene sheet surface to evaluate the charging unit on four different charging speeds of 0.01, 0.02, 0.03, 0.04 and 0.05 $\mathrm{ms}^{-1}$ using three different ranges of high voltages and four different thickness of the polyethylene sheet ( $a, b, c, d$, and e). The polyethylene sheets surface was treated with 3\% chitosan solution (weight basic) after the polyethylene sheet surface was charged with electrostatic charge unit to modify and improve antimicrobial properties of polyethylene sheet surface as packaging materials for extend shelf life of sweet pepper. The
\end{abstract}

\footnotetext{
${ }^{1}$ MSc. Student, Dept. of Agric. Eng., Faculty of Agriculture, Kafrelsheikh University 33516, Egypt

${ }^{2}$ Associate Prof. of Agric. Eng., Dept. of Agric. Eng., Faculty of Agric., Kafrelsheikh Univ. 33516 Egypt. E-mail: aelsbaay@yahoo.com

${ }^{3}$ Emeritus Associate Prof. of Agric. Eng. Dept. of Agric. Eng., Faculty of Agriculture, Kafrelsheikh University, 33516 Egypt

${ }^{4}$ Agricultural Bio - Engineering Professor Agric. Eng.Res.Institue, Dokki, Giza, Egypt.
} 
obtained results concluded that the polyethylene sheet (type a) gave the highest value of electrostatic charge at the highest voltage range difference. Charged polyethylene sheet surface and chitosan treated gave a high antimicrobial properties against listeria monothytogene, fusariumoxysporum and Pseudomonase aeroginosa. Finally, charged polyethylene sheet surface and chitosan treated during the sweet pepper storage period gave lower values of weight loss, $\mathrm{pH}$ and total aerobic bacteria count as well as yeast and mold count than other samples

Key words: surface modification, electrostatic, solar PV

\section{INTRODUCTION}

$\mathrm{E}$ gypt has a high potential of solar energy, which can be considered as a reliable energy source even during the winter season .It lies within the subtropical region. The annual daily average of solar radiation on horizontal plane in Egypt is $8 \mathrm{Kw} /\left(\mathrm{m}^{2}\right.$.day), The average solar radiation intensity during winter is about $7 \mathrm{~kW} /\left(\mathrm{m}^{2}\right.$.day), and the measured annual dailysunshine duration amounts to approximately 11 hrs.(Moharam,1993). The efficiency of the PV system depends on several factors such as isolation, ambient temperature, module temperature and the state of the solar panels such as ageing, cleanliness, etc.(Chokmaviroj, Wattanapong, and Suchart 2006; Kim 2007).The maximum power of the PV system varies mainly with the incident solar radiation (insolation) and the temperature (Eltawil and Zhengming 2013). The positive corona was used, a thicker layer of epoxy/polyester hybrid and greater improvement in adhesion for epoxy nylon and diacon were observed (Dastoori ,2001). There are several types of active packaging, including gas, moisture and UV absorbers, as well as flavor, antioxidant and antimicrobial releasers. One of the most modern active packaging systems is antibacterial packaging that is able to kill or inhibit the growth rate of microorganisms that contaminate foods. The antibacterial packaging films can be made by incorporation and immobilization of antibacterial substances in packaging materials (Appendini and Hotchkiss, 2002). Electrostatic coating studies on food powders have shown better coating utilizing negative corona than utilizing the traditional method where coating depends mostly on gravity 
and the shaking action of the machine (Biehl and Barringer,2004). Food coating/packaging is intended to provide some level of protection , prevent the transfer of materials from one food component to another, enhance the appearance of fruits and vegetables, and frequently contains other compounds to retard insects, microorganisms, oxidation and other intruders that would spoil the product (Brody , 2005). Plestenjak et al (2008) studied the influence of different storage conditions $(100 \% \mathrm{~N} 2$; $5 \% \mathrm{O} 2 ; 95 \% \mathrm{~N} 2 ; 10 \% \mathrm{O} 2 ; 90 \% \mathrm{~N} 2$; Normal atmosphere; $70 \% \mathrm{O} 2 ; 30 \%$ $\mathrm{N} 2$ and $100 \% \mathrm{O} 2$ ) on storability of shredded cabbage in different packing [fresh cut cabbage in PE film with an initial atmosphere of $100 \% \mathrm{O} 2$ and stored at $0{ }^{\circ} \mathrm{C}$.glass jar, polyethylene (PE) or polypropylene (PP)] for 7 days at $0{ }^{\circ} \mathrm{C}$ and $10{ }^{\circ} \mathrm{C}$. Variation in $\mathrm{CO} 2$ and $\mathrm{O} 2$ concentration was higher at $10{ }^{\circ} \mathrm{C}$ as compared to $0{ }^{\circ} \mathrm{C}$ and highest at atmosphere consisting of $70 \% \mathrm{O} 2 / 30 \% \mathrm{~N} 2$. A decrease of $\mathrm{O} 2$ below 3-5\% and increase of $\mathrm{CO} 2$ above $2-5 \%$ resulted in anaerobic metabolism in the packages. The best results were achieved by packging. Surface modification and surface coating are the most applicable methods used for the fabrication of antimicrobial packaging films. corona discharge is used in air purifiers to clean air by ionizing the air .Ozone is a by -product of corona discharge and it is used to kill microbes and neutralize airborne contaminants( Sanchez-Valdes et al .,2009). Active packaging is an innovative area, which causes food products to have better sensorial features and extended shelf-life, thus ensuring enhanced food quality and safety (Soares et al .,2009).

Vegetables form a vital constituent of the diet, where the population is predominantly vegetarian and thus vegetable cultivation is a significant part of the agricultural economy .Despite of stress conditions during open field cultivation, pepper fruits must customize the high frozen and processing industry demands uniform morphological characteristics, proper technological features and chemical composition (Chandrasekharam 2012).

The main objective of this study is using of solar photovoltaic cells for operating a locally manufactured electrostatic charging unit, which used to charge and modify polyethylene sheet surface as packaging materials for extend shelf life of sweet pepper 


\section{MATERIAL AND METHODS}

The study experiment was carried out at Agriculture Engineering Department, Faculty of Agriculture, KafrElsheikh University, KafrElsheikh Governorate, $\left(31.07 \mathrm{~N}^{\circ}\right.$ and $\left.30.57 \mathrm{E}^{\circ}\right)$, Egypt during the period of June to September, 2016 to find some solutions for extend shelf life of sweet pepper through a locally manufactured electrostatic charging unit operating with solar energy and use this unit for charging polyethylene sheet surface to modify and improve its antimicrobial properties as packaging materials.

The experimental charging unit consists of photovoltaic panel used for converting solar energy to electrical power by using charger and battery to storage the electrical power then electrostatic discharge unit which consist of electrostatic discharge high voltage convert the low voltage from $(12 \mathrm{v}$ to $80000 \mathrm{v})$ that connected with motor speed control unit for different velocities and types of plastic sheets. Figure (1) shows a photograph of locally manufactured electrostatic charging unit.

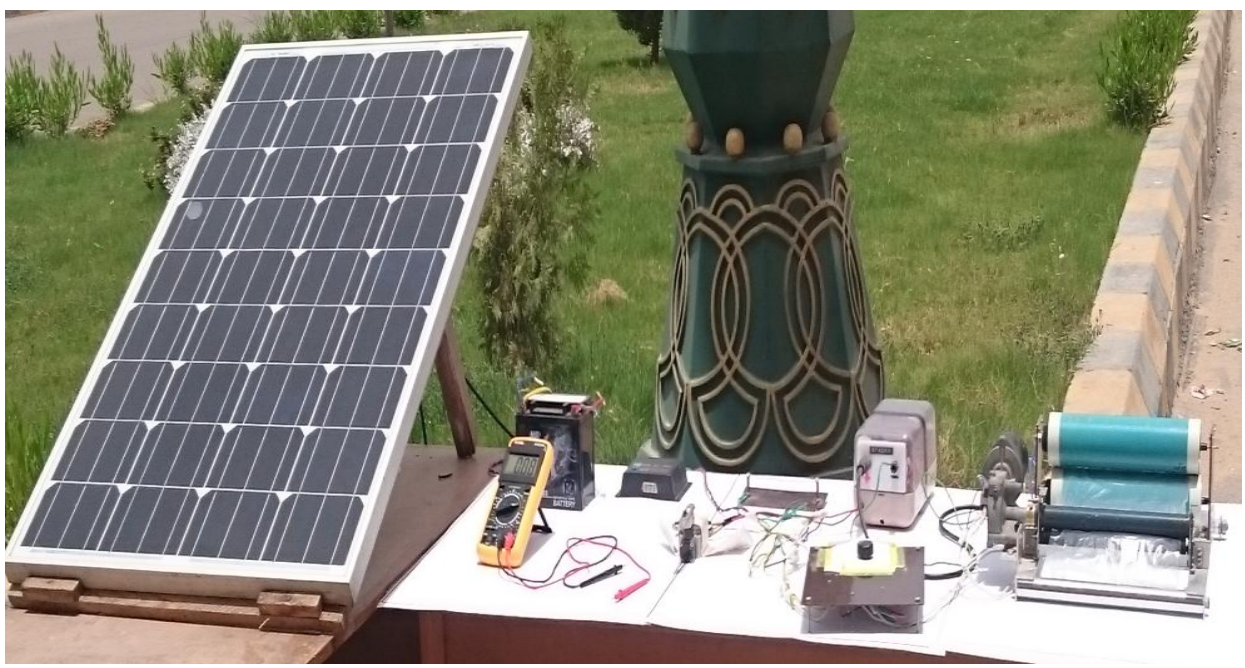

Fig (1): A photograph of electrostatic discharge unit manufactured locally

The photovoltaic array consists of one module $(100 \mathrm{~W})$ which were installed and fixed on a rectangular wooden frame and mounted on 31。 (latitude of the location) from the horizontal plane. Table (1) shows the specifications of module. 


\section{Table 1:PV cells specifications}

\begin{tabular}{l|l|l}
\hline Max- power & $\mathrm{pm}(\mathrm{W})$ & 100 \\
Power tolerance & $\%$ & $\pm 3 \%$ \\
Max-power voltage & $\mathrm{v}_{\mathrm{m}}(\mathrm{V})$ & 17.5 \\
Max-power current & $\mathrm{I}_{\mathrm{m}}(\mathrm{A})$ & 5.71 \\
Open-circuit voltage & $\mathrm{V}_{\mathrm{oc}}(\mathrm{V})$ & 21.9 \\
Short-circuit current & $\mathrm{I}_{\mathrm{sc}}(\mathrm{A})$ & 6.09 \\
Max-system voltage & $(\mathrm{VDC})$ & 1000 \\
Dimension & $(\mathrm{mm})$ & $1066 \times 674 \times 35$ \\
Weight & $(\mathrm{Kg})$ & 8.45 \\
Test condition & & $1000 \mathrm{~W} / \mathrm{m}^{2} \mathrm{AMI} .5,25 \mathrm{C}^{\circ}$ \\
\hline
\end{tabular}

The electrostatic charge treatment of polyethylene sheet surface was carried out in the air under atmospheric pressure using a locally manufactured charge unit. The schematic diagram of the electrical circle of the high voltage power supply shown in Figure (2).

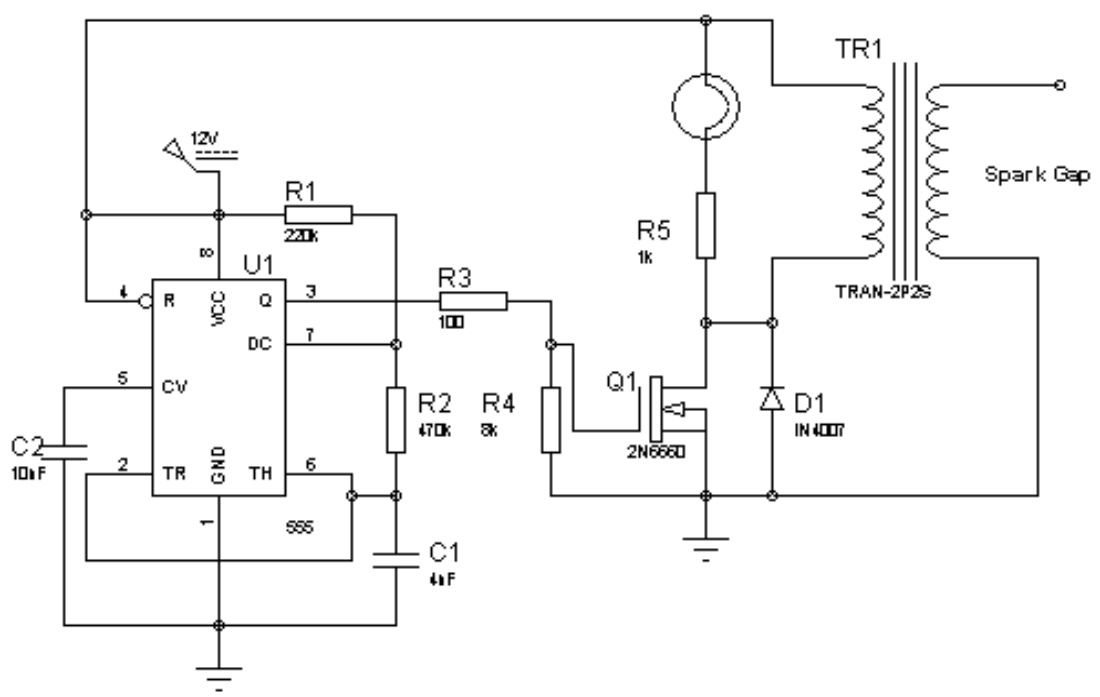

Fig (2): The schematic diagram of the electrical circle of the high voltage power supply.

A control unit of motor speed was locally manufactured by using some of electronic components as shown in Figure (3) and Figure (4) . 


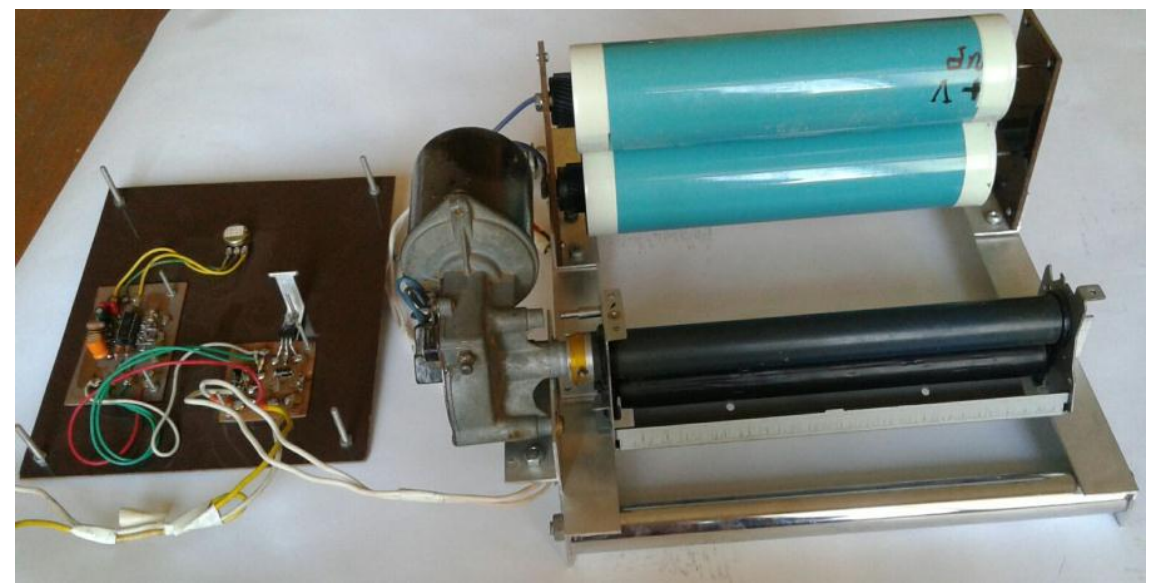

Fig (3): A photograph of motor speed control unit

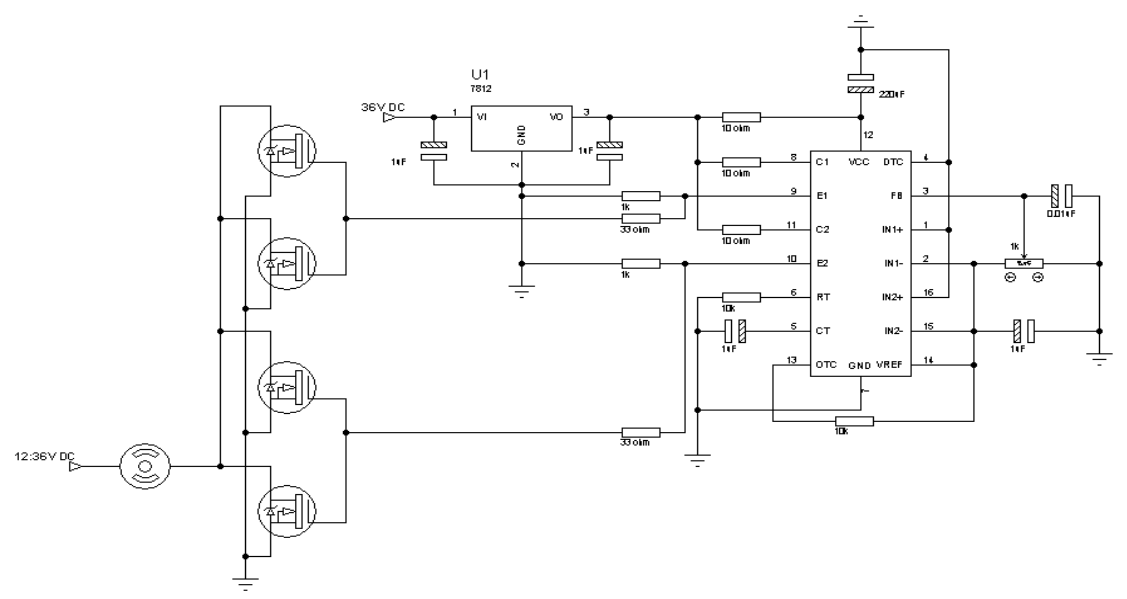

Fig (4): The schematic diagram of electrical circle of motor speed control unit.

A solar radiation sensor, Model TES 1333R Data logging solar power meter was used for measuring the solar radiation accuracy( within \pm $10 \mathrm{~W} / \mathrm{m} 2$ ) Air temperature was measured by an indoor outdoor thermometer with hygrometer clock and temperature panel were measured by an infrared thermometer. The DC open circuit voltage (Voc, V), load voltage (VL, V), short circuit current (Isc, A) and load current(IL, A) of the PV panel were measured with the help of Unit-T multimeter, Model DT830B.and used to measured volt and current to calculate electrical charge. Study parameters: 
1. Three different ranges of high voltage (42386.6, 45026.6 and 59999.9 V) for charging.

2. Five thickness and densities of polyethylene sheet as shown in table (2)

Table (2) shows experimental polyethylene specifications.

\begin{tabular}{|c|c|c|}
\hline Plastic type & Thickness, $\mathrm{mm}$ & Density, $\mathrm{g} / \mathrm{cm}^{3}$ \\
\hline $\mathrm{a}$ & 0.0275 & 0.966 \\
\hline $\mathrm{b}$ & 0.05125 & 0.970 \\
\hline $\mathrm{C}$ & 0.015 & 0.908 \\
\hline $\mathrm{d}$ & 0.02625 & 0.976 \\
\hline $\mathrm{e}$ & 0.095 & 1.368 \\
\hline
\end{tabular}

3. Three different treatment of storage treatments (Storage using electrostatic charged polyethylene sheet with chitosan treatment, Storage using electrostatic charged polyethylene sheet without chitosan treatment and Storage in the same condition without using polyethylene sheet.

Chitosan coating on to the polyethylene sheet surface was achieved by film dipping into chitosan solutions $3 \mathrm{wt} \%$ for 3 hours. After that the polyethylene sheets was removed and placed in circular oven controlled at $100{ }^{\circ} \mathrm{c}$ for 20 minutes.( Wu et al., 2012) .

Sweet pepper was selected for uniformity, shape, colour, size and any blemished or diseased were discard . the sweet pepper samples $(25 \mathrm{~g} \cong)$ was randomly divided into three groups the first one was without packaging, second one packaging with native polyethylene and last one packaging with modified polyethylene at $4^{\circ} \mathrm{C}$ for twenty one day. The sample tested every three days. Weight loss, $\mathrm{Ph}$ value, titratable acidity, total microbial count, yeast and moulds count were determined by methods described in AOAC(2000).

\section{RESULTS AND DISCUSSIONS}

\subsection{Solar photovoltaic panel:}

Figure (5) shows the effect of environmental conditions on PV power output $\left(\mathrm{PV}_{\text {output }}\right), \mathrm{PV}$ conversion efficiency on typical clear sunny days during the produces the experiment. The analysis of recorded data indicated that the power output of the solar photovoltaic changed 
significantly with insolation. The daily average insolation measured on the panel surface for different clear sunny days was $611.76 \mathrm{w} / \mathrm{m}^{2} / \mathrm{d}$ during experimentation. Results revealed that the $\mathrm{PV}_{\text {output }}$ was proportional to insolation, while PV panel temperature $(T \mathrm{p})$ was directly proportional to insolation and ambient temperature (Tamb).
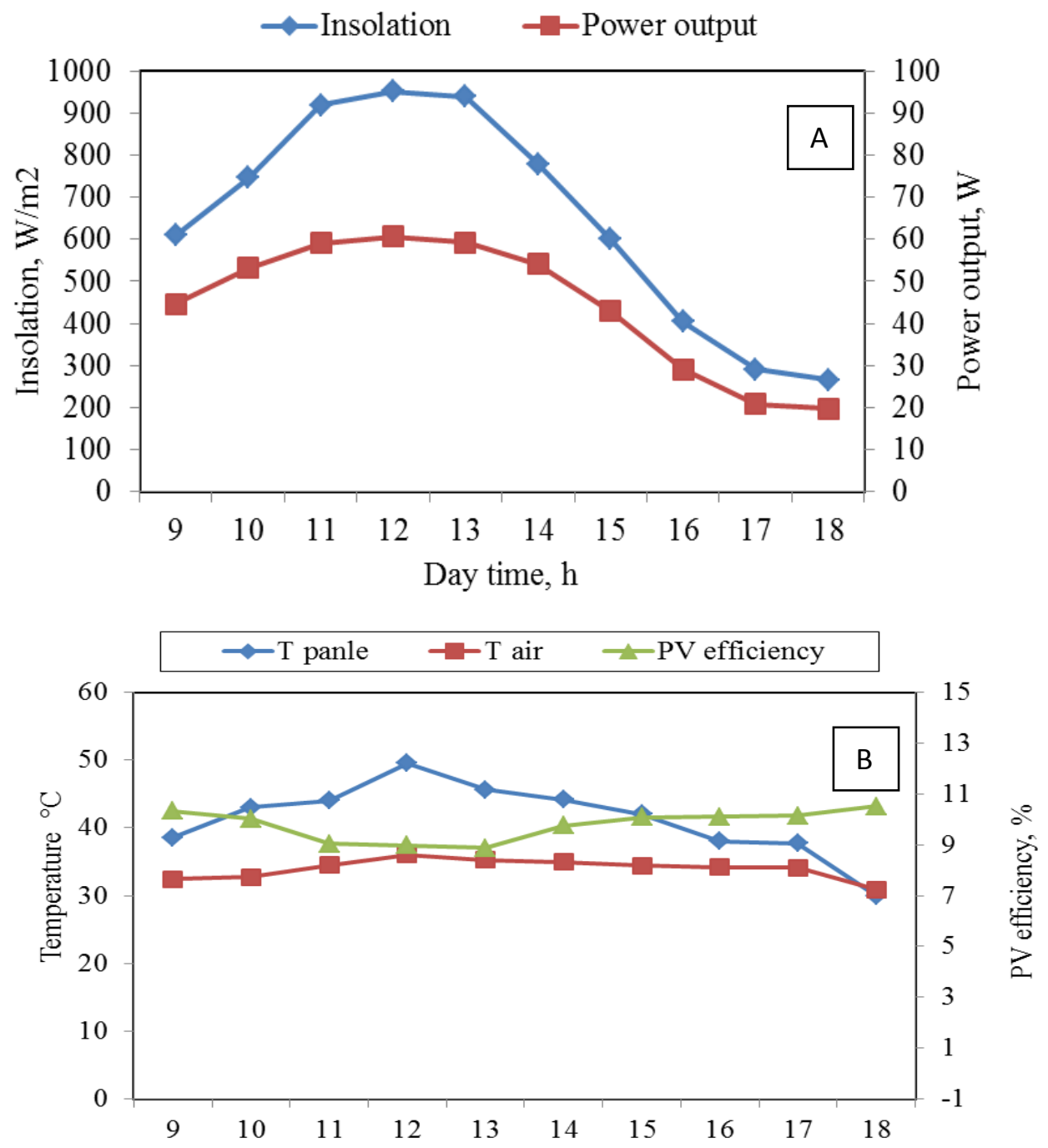

Day Time, h

Fig( 5): Effect of ambient conditions on PV power output, PV conversion efficiency for typical clear sunny day during the experiment . 
It was found that increasing the module/panel temperature causes a rise in the short circuit current and a decrease in Voc. This increase in module temperature would arise due to high insulation heating, high ambient temperature, with consequent from the module to the ambient. For this reason, maximum open circuit voltages were recorded in the mornings when the module/panel has not yet been heated up, while maximum short circuit currents (Isc) were recorded at noon. This is in agreement with observation made by Eltawil and Elsebaay 2014.

\subsection{Power consumption:}

The power consumption and the electrical current were direct proportion to the voltage as shown in figure (6). The power consumptions were 14.2, 31.2 and 46.2 watt at $4.2,5.1$ and $5.7 \mathrm{~V}$ respectively

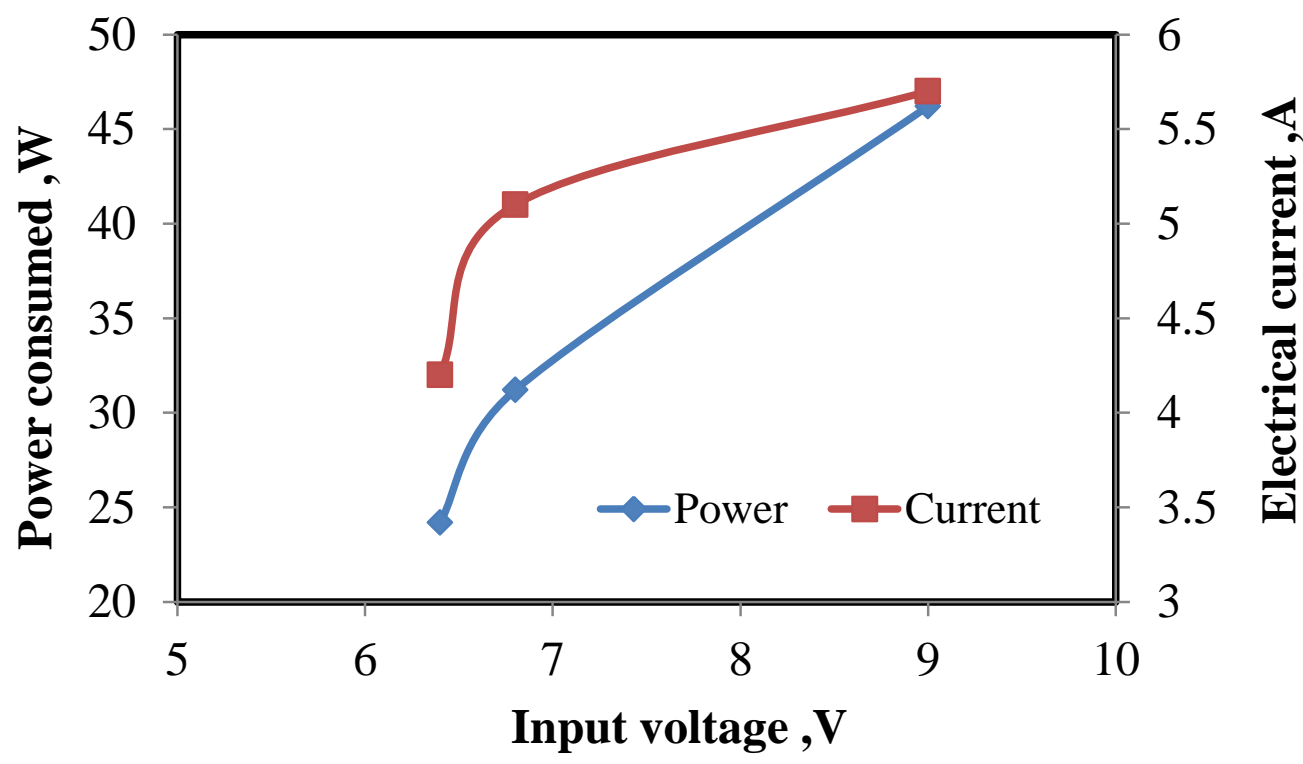

Fig (6): shows power consumption and electrical current for voltage.

\subsection{Electrostatic discharge for plastic sheet under different speeds:-}

Figure (7) shows that electrostatic discharge stored in different types of plastic sheet and different high voltage. At thickness of $0.0275 \mathrm{~mm}$ (type of plastic sheet a) the total charge stored in conductors were 3678.7 , 4034.7 and 5458.7 nf.v at high voltage 41333.3, 45333.3 and $61333.3 \mathrm{~V}$ respectively. At thickness of $.0 .0512 \mathrm{~mm}$ (type of plastic sheet b) the total charge stored in conductors were $3683.3,3836.3$ and 53833.3nf.v at 
high voltage $4333.3,45133.3$ and $63333.3 \mathrm{~V}$ respectively. At thickness of $.0 .015 \mathrm{~mm}$ (type of plastic sheet c) the total charge stored in conductors were 3488.8, 3920 and $4704 \mathrm{nf} . \mathrm{v}$ at high voltage 41533.3, 46666.6 and $56000 \mathrm{~V}$ for respectively. At thickness of $.0 .0262 \mathrm{~mm}$ (type of plastic sheet d) the total charge stored in conductors were $3688.8,3654$ and $4872 \mathrm{nf} . \mathrm{v}$ at high voltage 42400,44200 and $56000 \mathrm{~V}$ respectively. Also At thickness of $0.095 \mathrm{~mm}$ (type of plastic sheet e) the total charge stored in conductors were $3726.6,3956$ and 5446.6nf.v at high voltage 43333.3, 46000 and $63333.3 \mathrm{~V}$ respectively .

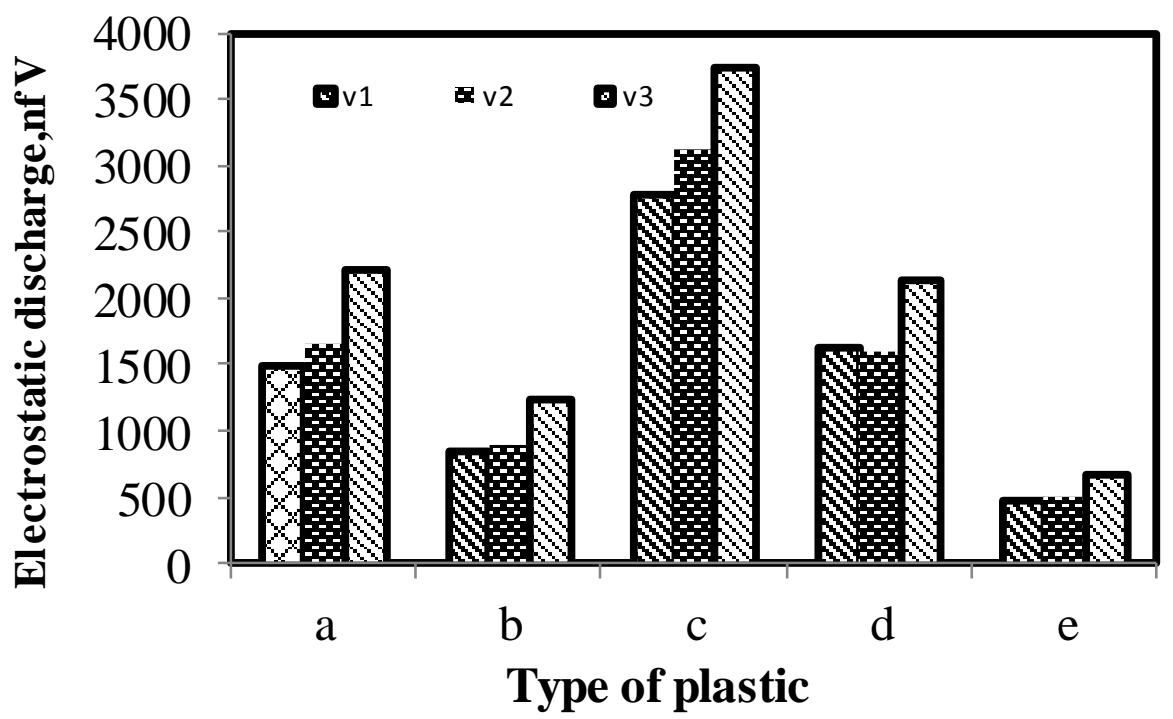

Fig( 7): shows electrostatic discharge for different thickness of plastic sheets. $(a=0.0275 \mathrm{~mm}, b=0.0512 \mathrm{~mm}, c=0.015 \mathrm{~mm}, \mathrm{~d}=0.0262 \mathrm{~mm}, \mathrm{e}=$ $0.095 \mathrm{~mm})$

The best results of electrostatic charged polyethylene sheet was obtained for sheet type a at charging and this condition was taken as the optimum for packaging sweet pepper with/without chitosan treatment for shelf life experiment compared with treatment storage in the same condition without using polyethylene sheet. 


\subsection{Total aerobic bacteria :}

Data tabulated in table (3)shown that ,aerobic plate count increased significantly during storage for all investigated samples, the recorded results were in the same line with those reported by Ruiz -Cruz et al.(2010).

Table (3) Effect of packaging conditions of polyethylene sheets on aerobic plate count $(\log \mathrm{CFU} / \mathrm{g})$ sweet pepper during storage period at $4{ }^{\circ} \mathrm{C}$.

\begin{tabular}{|c|c|c|c|}
\hline $\begin{array}{c}\text { Storage } \\
\text { period (day) } \\
\text { at } 4{ }^{\circ} \mathrm{C} .\end{array}$ & $\begin{array}{c}\text { Without } \\
\text { packaging by } \\
\text { polyethylene } \\
\text { sheet control }\end{array}$ & $\begin{array}{c}\text { Packaging by } \\
\text { charged } \\
\text { polyethylene } \\
\text { only }\end{array}$ & $\begin{array}{c}\text { Packaging by } \\
\text { charged } \\
\text { polyethylene } \\
\text { coated with } \\
\text { chitosan 3\% }\end{array}$ \\
\hline 0 & 3.23 & 3.23 & 3.23 \\
\hline 7 & 3.71 & 3.54 & 3.31 \\
\hline 14 & 4.58 & 4.32 & 3.82 \\
\hline 21 & & 4.48 & 3.97 \\
\hline
\end{tabular}

Data in table (3)shown that, aerobic plate count was increased in sweet pepper from 3.23 log CFU/g to 4.58,4.48 and 3.97 log CFU/g at the end of experiment period in case of sweet pepper Without packaging by polyethylene sheet control, sweet pepper Packaging by charged polyethylene only and the third ones Packaging by charged polyethylene coated with chitosan $3 \%$, respectively these results were in the same line with those of Ediriweera et al .(2014) .

\section{5. antimicrobial activity}

Modiyfied low density polyethelene by chitosan possessed noticeable inhibitory against listeria monothytogenes, Pseudomonase aeroginosa and activity against fungi (fusarium oxysporum) . from date given in table (4) its clear that, modified low density polyethylene by chitosan gave the highest wide inhibition zones $(6.14 \mathrm{~mm})$, followed by that of native polyethylene Generally, all tested of modified low density polyethylene by chitosan showed effective antimicrobial activity againstgram positive bacteria (Pseudomdnaseaeroginosa).

\subsection{Mould and Yeast count:}

From data given in table(5), it could be noticed that, moulds and yeasts count increased significantly during storage for all investigated samples. 
The received results were in the same line with those reported by (RuizCruz et al .,2010. ) .

Table (4):diameters of inhibition zone $(\mathrm{mm})$ results indicator of filmtype

\begin{tabular}{|c|c|c|c|}
\hline \multirow[b]{2}{*}{$\begin{array}{l}\text { Film } \\
\text { type }\end{array}$} & \multicolumn{3}{|c|}{ Inhibition zone (mm) } \\
\hline & $\begin{array}{c}\text { Listeria } \\
\text { monocytogenes }\end{array}$ & Psendomonaseaeroginosa- & $\begin{array}{l}\text { Fusaruim } \\
\text { oxysporum }\end{array}$ \\
\hline G1 & 6.14 & 5.11 & 3.02 \\
\hline G2 & 5.97 & 5.00 & 2.8 \\
\hline G3 & 5.72 & 4.89 & 2.63 \\
\hline G4 & 5.41 & 4.6 & 2.30 \\
\hline G5 & 0.00 & 0.00 & 0.00 \\
\hline
\end{tabular}

Table 5: Effect of packaging conditions on moulds and yeasts count $(\log \mathrm{CFU} / \mathrm{g})$ sweet pepper during storage at $4^{\circ} \mathrm{C}$.

\begin{tabular}{|c|c|c|c|}
\hline $\begin{array}{c}\text { Storage } \\
\text { period (day) } \\
\text { At } 4{ }^{\circ} \mathrm{C}\end{array}$ & $\begin{array}{c}\text { Without } \\
\text { packaging by } \\
\text { polyethylene } \\
\text { sheet control }\end{array}$ & $\begin{array}{c}\text { Packaging by } \\
\text { charged } \\
\text { polyethylene } \\
\text { only }\end{array}$ & $\begin{array}{c}\text { Packaging by } \\
\text { charged } \\
\text { polyethylene } \\
\text { coated with } \\
\text { chitosan 3\% }\end{array}$ \\
\hline 0 & 0.230 & 0.230 & 0.230 \\
\hline 7 & 0.410 & 0.305 & 0.291 \\
\hline 14 & 0.811 & 0.573 & 0.377 \\
\hline 21 & ------------------ & 0.738 & 0.492 \\
\hline
\end{tabular}

The results in the same table showed that the total count of moulds and yeasts increased in sweet pepper from $0.230 \mathrm{log} \mathrm{CFU} / \mathrm{g}$ to $0.811,0.738$ and $0.492 \log \mathrm{CFU} / \mathrm{g}$ at the end of experiment period in case of without packaging by polyethylene sheet control sweet pepper, sweet pepper packaged with native polyethylene sheets and the third ones were packaged with modified polyethylene sheets, respectively

\section{7. $\mathrm{PH}$ value}

The value of $\mathrm{pH}$ in samples of sweet pepper during storage period was measured and the obtained results were summarized in Table (6).As shown in Table (6) $\mathrm{pH}$ value was increased in sweet pepper from 3.71 at 
zero time to $4.63,4.50$ and 4.00 at the end of experiment in case of Without packaging by polyethylene sheet control sweet pepper, sweet pepper Packaging by charged polyethylene only and the third ones were Packaging by charged polyethylene coated with chitosan $3 \%$.

Table (6): Effect of packaging conditions on sweet pepper PH values during storage period at $4{ }^{\circ} \mathrm{C}$.

\begin{tabular}{|c|l|l|l|}
\hline $\begin{array}{c}\text { Storage } \\
\text { period (day) } \\
\text { at } 4{ }^{\circ} \mathrm{C} .\end{array}$ & $\begin{array}{l}\text { Without } \\
\text { packaging } \\
\text { polyethylene } \\
\text { sheet control }\end{array}$ & $\begin{array}{l}\text { Packaging by } \\
\text { charged } \\
\text { polyethylene } \\
\text { only }\end{array}$ & $\begin{array}{c}\text { Packaging by } \\
\text { charged polyethylene } \\
\text { coated with chitosan } \\
3 \%\end{array}$ \\
\hline 0 & 3.71 & 3.71 & 3.71 \\
\hline 7 & 4.52 & 4.20 & 3.86 \\
\hline 14 & 4.63 & 4.32 & 3.95 \\
\hline 21 & & 4.50 & 4.00 \\
\hline
\end{tabular}

\subsection{Titratable acidity :.}

Titratable acidity is an important factor in maintaining the quality of some fruits and vegetables, which is directly related to concentration of organic acids present in these products. Organic acids exist as free acids, anions (malate) or combined as salt (potassium bitartarte ) and esters such as isopentyle acetate (Kays, 1991). The values of the Titratable acidity in sweet pepper during storage period were summarized in Table (7)

Table (7) Effect of packaging conditions of polyethylene on titratable acidity values in sweet pepper during storage period at $4{ }^{\circ} \mathrm{C}$.

\begin{tabular}{|c|c|c|c|}
\hline $\begin{array}{c}\text { Storage } \\
\text { period (day) } \\
\text { at } 4{ }^{\circ} \mathrm{C} .\end{array}$ & $\begin{array}{c}\text { Without } \\
\text { packaging by } \\
\text { polyethylene } \\
\text { sheet control }\end{array}$ & $\begin{array}{c}\text { Packaging by } \\
\text { charged } \\
\text { polyethylene } \\
\text { only }\end{array}$ & $\begin{array}{c}\text { Packaging by } \\
\text { charged } \\
\text { polyethylene } \\
\text { coated with } \\
\text { chitosan 3\% }\end{array}$ \\
\hline 0 & 3.50 & 3.50 & 3.50 \\
\hline 7 & 1.90 & 2.80 & 3.30 \\
\hline 14 & 1.59 & 2.30 & 3.00 \\
\hline 21 & & 2.00 & 02.50 \\
\hline
\end{tabular}


Data in table (7) showed that ,titratable acidity content decreased during storage for all investigated as shown in table (7), titratable acidity was reduced in treated samples from 3.50 to $1.59,2.00$ and 2.50 at the end of storage period for the follow sweet pepper samples (Without packaging by polyethylene sheet control, Packaging by charged polyethylene only Packaging by charged polyethylene coated with chitosan $3 \%$ ),respectively.

\subsection{Weight loss:}

Weight is considered one of great important properties because it can cause fruit shriveling and advance senescence. it is mostly depends on relative humidity surrounding the fruit, but can also be associated with a slight reduction in flesh firmness(Ishaq et al.,2009). Therefore, the weight loss was taken as indicator for water loss in sweet pepper during storage period and the obtained results were tabulated in Table (8)

Table (8): Effect of packaging conditions of polyethylene sheet on sweet pepper weight lose $\%$ during storage period at $4 \mathrm{c}$.

\begin{tabular}{|c|c|c|c|}
\hline $\begin{array}{c}\text { Storage } \\
\text { period (day) } \\
\text { At 4 c }\end{array}$ & $\begin{array}{c}\text { Without } \\
\text { packaging by } \\
\text { polyethylene } \\
\text { sheet control }\end{array}$ & $\begin{array}{c}\text { Packaging by } \\
\text { charged } \\
\text { polyethylene } \\
\text { only }\end{array}$ & $\begin{array}{c}\text { Packaging by } \\
\text { charged } \\
\text { polyethylene } \\
\text { coated with } \\
\text { chitosan 3\% }\end{array}$ \\
\hline 0 & 0.00 & 0.00 & 0.00 \\
\hline 7 & 5.38 & 4.73 & 3.12 \\
\hline 14 & 11.23 & 9.67 & 6.25 \\
\hline 21 & & 10.23 & 8.42 \\
\hline
\end{tabular}

Table (8) shown that, without packaging by polyethylene sheet control samples had the highest weight loss during storage, followed by samples Packaging by charged polyethylene only, while the lowest weight loss was detected in case of Packaging by charged polyethylene coated with chitosan $3 \%$. Plastic film materials are known to reduce water loss during prolonging storage. The reduction in water loss observed in the polyethylene bags plays a key role by serving as a tight barrier to water evaporation. This explains why samples kept without packaging by 
polyethylene sheet control lost high amount of water because they offered less resistance to water loss. It should be also noticed from the same table that,weight loss was ranged in sample without packaging by polyethylene sheet control from 0.00 to $11.23 \%$; samples Packaging by charged polyethylene only,from 0.00 to $10.23 \%$ and samples Packaging by charged polyethylene coated with chitosan $3 \%$ from 0.00 to $8.42 \%$.

\section{CONCLUSION}

From the obtained results and its discussion concluded that using electrostatic discharge unit very useful for improving the polyethylene type a to extend shelf life of sweet pepper up to 21 days during storage period. The antimicrobial activity increased and total count of aerobic bacteria, mould and yeast decreased due to using charged and chitosan $3 \%$ treated of polyethylene sheets for packaging sweet pepper during storage period. The author recommended to manufactured mobile unit of electrostatic discharge which operated by solar energy and easy to use and distribute this producer technique to extend the shelf life of sweet pepper during transporting fresh for market or for exporting.

\section{REFERENCES}

AOAC ( Association of Official Ana lytical Chemistis ).(2002).Official Methods Of Analysis.;17 th Ed .Washington, D.C,USA.

Appendin, p. and Hotchkiss, J. H.(2002). Review of antimicrobial food packaging .Innovative Food Science \&Emerging Technologies, 3(2),113-126.

Biehl, H .L. and Barringer ,S.A.(2004). Comparison of the effect of powder properties on coating transfer efficiency and dustiness in two non -electrostatic system, Innov . Food Sci. Emerg. Technol. 5:191-198.

Brody ,A .L. (2005).Edible packaging .Food Tech ,pp.56 ,65 .

Chandrasekharam D (2012) http://dchandra.geosyndicate.com 
Chokmaviroj, S., R.Wattanapong, andY. Suchart. (2006). "Performancof a $500 \mathrm{kWp}$ Grid Connected Photovoltaic System at Mae HProvince, Thailand." Renewable Energy 31: 19-28.

Dastoori ,K.;Makin, B. and Telford, J.(2001). Measurements of thickness and adhesive properties of electrostatic powder coatings fstandard and modified powder coating guns, J. Electrostat. 51-25:545-551.

Ediriweera, s.;Abeywickrama , k .; Latifah,M.; Othman,F.; wan Hussin , R.\&Tham, S.(2014).Quality of minimally processed, modified atmosphere stored bell pepper, as affected by pretreatment. Tropical Agricultural Research and Extension 16(2).

Eltawil, M. A., and A. M. ElSbaay. 2014 "Utilisation of solar photovoltaic pumping for aeration systems in aquaculture ponds." International Journal of Sustainable Energy .

Eltawil, M. A., and Z. Zhengming. (2013). "MPPT Techniques for PV Applications." Renewable and Sustainable Energy Reviews 25 (September): 793-813.

Ishaq, S;Rathore, H.A;Majeed,S.; Awan, S. and Zulifiqar-AliShah,S.(2009). The studies on the physic-chemical and organoleptic characteristics of apricot(prunusarmaniaca L.) produced in Rawalakota,Azad Jammu and Kashmir during storage .Pakistan journal of Nutrition.8(6);856-860.

Kays, s.j. (1991).Post Harvest Physiology of Perishable Plant Products .Vas Nostrand Rein Hold Book, AVI publishing Co., pp149-316.

Plestenjak A, Pozrl T, Hribar J, Unuk T and Vidrih R (2008) Regulation of metabolic changes in shredded cabbage by modified atmosphere packaging. J Food Technol Biotechnol 46: 427-33.

Ruis-cruz,s:,Alvarez-parrilla,E.;delaRosa,L.A.;Martinez-

Gonzalez,A.I.;Orneles-paz,J.J.;Mendza-wilson,A.M.\&GonzalezAguilar,G.A.(2010) .Effect of different sanitizers on microbial , sensory and nutritional quality of fresh -cut jalapeno peppers . 
American journal of Agriculture and Biological sciences ,5(3):331341.

Sanchez-Valdes, S.; Ortega-Ortiz, H.; Ramos-de Valle, L.F. (2009) .; Medellin-Rodriguez, F.J. and Guedea-Miranda, R. J. Appl. Polym. Sci. 953-962.

Soares, F., Pires, A .C.S., Camilloto, G.P., Santiago-Silva, Espitia, P. P., J.P. \&Silva, W.A. (2009).Resent patents on active packaging for food application. Resent patents on food, nutrition \&agriculture,1,171-178.

Wu,J. .,Lee,G.J.,Chen , Y .S., and Hu , T .L. 2012 . The synthesis of chitosan polypropylene plastics for anti bacterial application. Current Applied physics, 12:89-95.

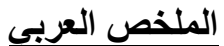

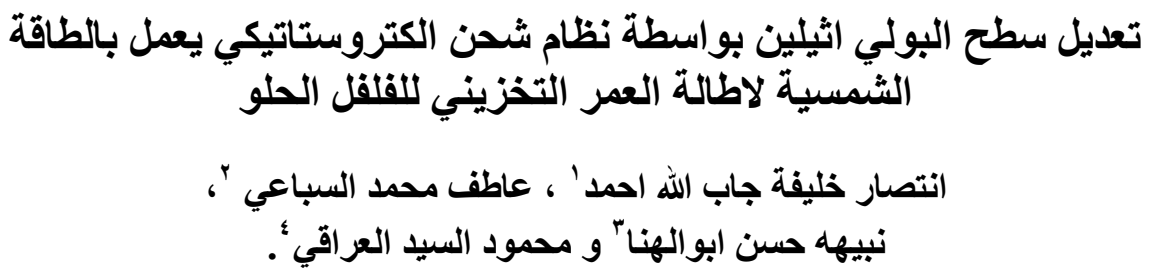

نظرا للزياده المطروده في انتاج الفلفل الحلو للاستهلاك الطازج او التصدير خلال الونه

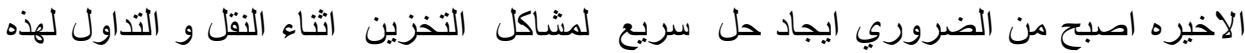

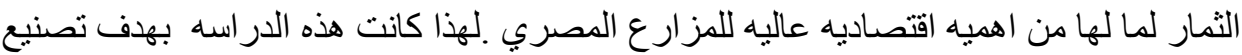

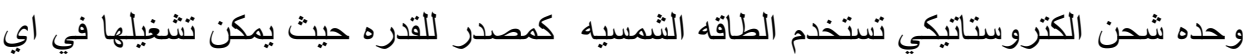
مكان كوحده متنقله للشحن الالكتروستاتيكي لاسطح البولي اليثليلين لاستخدامها في تغليف ثمار الفئ

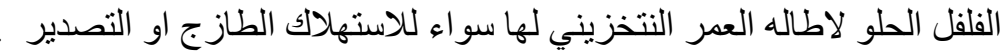

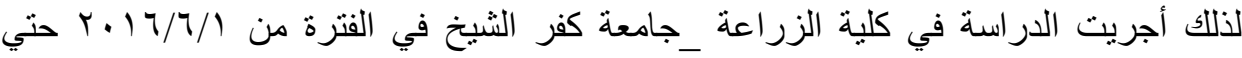

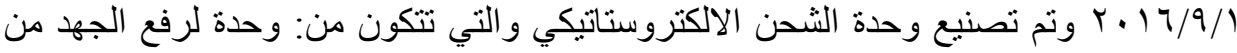

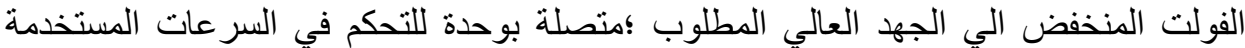

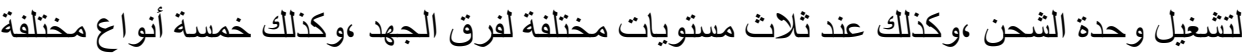

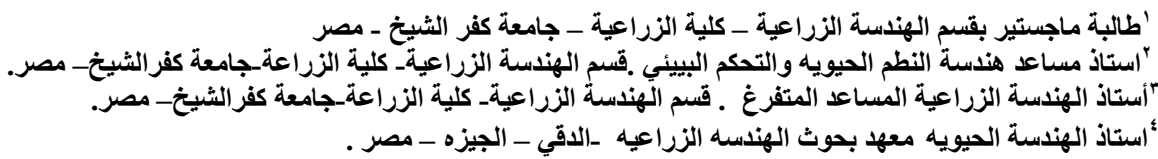


من البولي أيثيلين في السمك .نم شحن الأغلفة من البولي ايثلين بجهاز الثحن الإلكتروستاتيكي

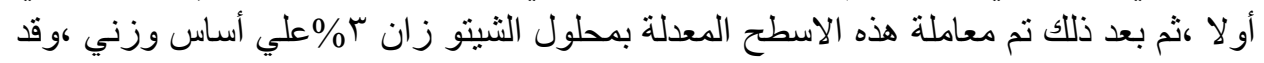

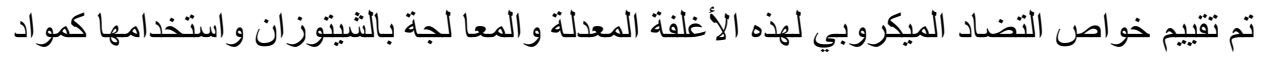

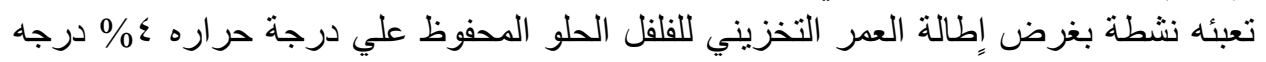

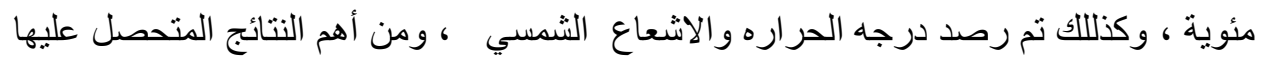

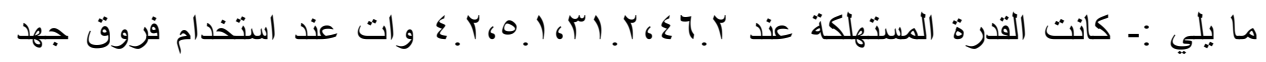

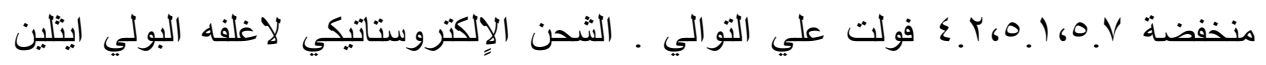

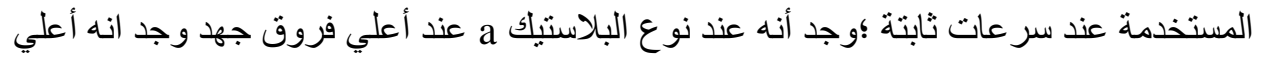

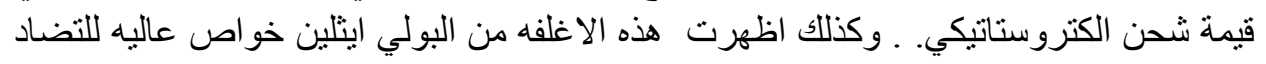

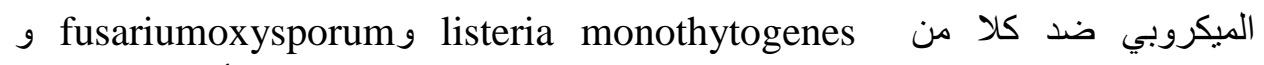
و aeroginosa Pseudomonase

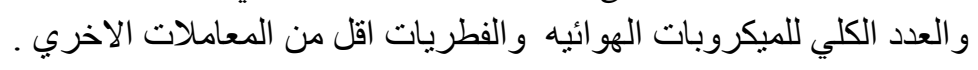

